\title{
IMPROVING INFLATION AND RELATED PERFORMANCE MEASURES FOR NATIONS: AN INTRODUCTION
}

\author{
Guest Editors: Robert J. HilL* \\ University of Graz \\ AND \\ Alice O. NaKamura \\ University of Alberta School of Business
}

\section{INTRODUCTION}

The World Congress on National Accounts and Economic Performance Measures for Nations brought together economic measurement experts from the universities, national statistical agencies, and central banks of more than a dozen countries and key international organizations. ${ }^{1}$ The Congress featured papers addressing measurement challenges identified in the research of the two scholars honored by the Congress: Erwin Diewert and Dale Jorgenson. ${ }^{2}$ This special issue consists of revised versions of papers drawn primarily from the Diewert-stream of the Congress program.

Diewert's research has been a defining force in the evolution of modern price measurement theory and practice. ${ }^{3}$ The 2004 and 2009 international price index manuals are a wonderful illustration of this point. ${ }^{4}$ While many experts from a large number of national and international statistical offices collaborated on the chapters on index number practice, the international agencies entrusted most of the chapters on index number methods to Erwin Diewert in recognition of his international reputation and outstanding contributions to the subject over the last few decades.

*Correspondence to: Robert J. Hill, Department of Economics, University of Graz, Austria (robert.hill@uni-graz.at).

${ }^{1}$ This Congress, held May 12-18 at the Key Bridge Marriot Hotel in Arlington, Virginia, was organized by Alice O. Nakamura (University of Alberta School of Business) and Richard B. Freeman (Harvard University, London School of Economics, and the NBER). More than 450 participants from 21 nations gathered together for presentations and discussion of the more than 200 papers. The program and papers can be found at http://www.indexmeasures.com/.

${ }^{2}$ Masahiro Kuroda, Chair of the Congress Awards Committee, delivered the following citation in naming the 2008 Laureates of the World Congress on National Accounts and Economic Performance Measures for Nations: "Our two colleagues, W. Erwin Diewert and Dale W. Jorgenson, provided the seminal beginnings for much that has become so accepted in the fields of growth accounting and index numbers that we all now use these insights and methods no longer stopping to remember who created them. But this did not happen without great effort. Year after year, Erwin and Dale nurtured and raised their numerous intellectual progeny."

${ }^{3}$ For example, the properties of superlative index numbers are developed and explained in Diewert (1976, 1978a, 1992a, 1992b, 1997, 2001, 2002a, 2002b), Caves et al. (1982a, 1982b), Diewert and Nakamura (1993), Diewert and Mizobuchi (2009), Diewert and Fox (2010a), Diewert et al. (2009), and Diewert and Hill (2010). National statistical agencies have recognized the importance of using superlative index numbers whenever possible. His influence operates through a wide network of former students and colleagues (e.g. Kohli, 1993; Feenstra, 1995; Hill, 2004; Diewert and Fox, 2008; Nakamura and Steinsson, 2008).

${ }^{4}$ See ILO et al. (2004) and IMF et al. $(2004,2009)$. The chapters authored or co-authored by Diewert are Chapters 15-20 and 22-23 of the new international Consumer Price Index Manual (the CPI Manual), and Chapters 15-22 of the new international Producer Price Index Manual (the PPI Manual). 
The papers in this special issue are arranged under headings for four areas where other researchers have pushed back the knowledge frontiers on questions to which Diewert has called attention in his own research. On each of these topics, as part of introducing the papers in this issue on that topic, we also provide some of the key references to Diewert's related work. We begin with the topic on which Diewert has a paper in this issue.

\section{Purchasing Power Parities}

The International Comparison Programme (ICP) is a worldwide statistical initiative which aims to enable output comparisons that are unaffected by price level differences among nations by producing expenditure side Purchasing Power Parity (PPP) estimates. For a single product, a PPP is just the ratio of the price of the product in one country to the price of the same quantity and quality of the product in another country. Just as time series of value figures must usually be adjusted to allow for inflation, value figures for different nations must be adjusted typically to allow for cross-country differences in the purchasing power of the national currencies. Before PPPs became available, exchange rates were used to approximate this adjustment. However, exchange rates, as the prices at which currencies trade in financial markets, are determined by the supply and demand for different currencies. Many goods and services are traded internationally little or not at all. Exchange rates are also sometimes subject to sudden fluctuations. ${ }^{5}$

There are two main approaches for adjusting value figures to account for country purchasing power differences. The first is the expenditure approach of the ICP pioneered by Heston, Kravis, and Summers. The second is the industry-oforigin approach of the International Comparisons of Output and Productivity (ICOP) project originated by Maddison (see van Ark et al., 2008). The ICOP project developed industry-specific conversion factors using producer output data, in contrast to the final expenditure information used in the ICP approach. These two approaches are complements rather than substitutes. The second approach is needed in studies that pay attention to the industry structure of economies. Looking to the future, Diewert argues that it would be desirable to better integrate the ICP, with its expenditure perspective, and the ICOP with its focus on producers.

The PPP papers here are associated with the ICP project. ${ }^{6}$ The results for the 2005 ICP were released in February 2008. The program compared the level of prices and the quantities or volumes of GDP (and its components) for 146 countries for the year 2005. In this round of the ICP, the world was divided into six regions: OECD, CIS, Africa, South America, Asia Pacific, and West Asia.

PPP compilation within the ICP is undertaken at two levels: at the basic heading level and at a more aggregated level. At the basic heading level, price data

${ }^{5}$ The volatility of exchange rates can, of course, be dealt with by means such as taking moving averages. For example, the Atlas conversion factor for a given year is the average of a country's exchange rate for that year and its exchange rates for the two preceding years, after adjusting for differences between the rate of inflation in the country and the G-5 countries. The three-year averaging of the Atlas method smoothes annual fluctuations in the resulting conversion factors, but cannot bring them closer to PPPs that adjust for inter-country price level differences.

${ }^{6}$ Diewert now chairs the Technical Advisory Group of the ICP. 
are aggregated without expenditure share weights to yield PPPs for various basic headings. The basic heading PPPs are then aggregated to yield PPPs for higher level aggregates like consumption, investment, and gross domestic product.

In previous ICP rounds, each country attempted to find prices in their country for a common product list. However, it is difficult to find products that are representative for all countries in the world. W. Erwin Diewert, in his 2008 World Congress Laureate Address published here (Diewert, 2010a) explains that a new innovation in this round of the ICP is that each region was allowed to develop its own product list and collect prices on this list for countries in the region, and then each region was independently allowed to determine its country PPPs. ${ }^{7}$ The regions were linked using a special product list for which 18 countries, spread across the six regions and referred to as ring countries, collected prices. The regions were linked at the basic heading level using a method proposed by Diewert (2004b, 2008).

The main statistical approach to the multilateral aggregation of prices at the first stage of aggregation is the Country Product Dummy (CPD) method, proposed by Summers (1973). Diewert explains that this method for making international comparisons of prices can be viewed as a simple type of hedonic regression model where the only characteristic of the commodity is the commodity itself, and also as an example of the stochastic approach to index numbers. ${ }^{8}$

Diewert notes that other possible methods could be used to link the regions and could form part of the research agenda for the next round of comparisons. In particular, he argues that it makes sense to compare countries whose (relative) price structures are similar and whose (absolute) quantity structures are similar, since index number comparisons of prices and volumes will work best under these conditions. This perspective suggests a strategy of choosing the order for linking countries by their degree of similarity. Thus roughly speaking, it makes sense to compare directly countries at the same stage of development and build up a complete set of multilateral comparisons by linking (bilaterally) countries that are most structurally similar. Diewert explains that Hill (1999a, 1999b, 2004) has developed a methodology along these lines, and recommends its use, on at least an experimental basis.

In their paper, Gholamreza Hajargasht and D. S. Prasada Rao demonstrate the versatility of the stochastic approach to price index construction (Hajargasht and Rao, 2010). Using a variety of estimation methodologies, such as weighted maximum likelihood and method of moments, they show that the stochastic approach can be used to derive a number of widely used multilateral index numbers. An important advantage of the stochastic approach is that it provides standard errors for the estimated purchasing power parities (PPPs). The results in this paper, which build on Diewert (1999, 2004a, 2005, 2010b), are of particular interest in an ICP context in that they develop new links between the CPD method and the Geary-Khamis and Iklé methods. The authors then present some examples of estimated PPPs and corresponding standard errors. The results clearly

\footnotetext{
${ }^{7}$ See, for example, the 2008 edition of the APO Databook (prepared by Koji Nomura, Eunice Lau, and Hideyuki Mizobuchi) for more on how PPPs were prepared in the West Asia region (http:// www.apo-tokyo.org/00e-books/IS-41_DB2010.htm). (2009a)

${ }^{8}$ Diewert has written a great deal on hedonics, including Diewert (2006a) and Diewert et al.
} 
demonstrate the feasibility and comparability of these new approaches to the estimation of PPPs.

The paper by D.S. Prasada Rao, Alicia Rambaldi, and Howard Doran presents an econometric framework for the construction of a consistent panel ofPPPs (Rao et al., 2010). Unlike the Penn World Table and similar tables produced by the World Bank, which tend to be anchored on a selected benchmark, the method presented here combines all available benchmarks and national accounts implicit deflators. The econometric formulation is based on a regression model for the national price levels where the disturbances are assumed to be heteroskedastic and spatially correlated across countries. The regression model along with data on country specific price movements are combined using a state-space formulation to generate optimal predictions of PPPs. The methodology is very flexible and can be applied to non-benchmark countries and non-benchmark years. The authors illustrate their methodology using a data set that covers 141 countries over the period 1970 to 2005.

\section{Dealing with the Growth of Multinational Firms}

Certain aspects of the profit seeking behavior of multinational firms pose special problems for statistical agencies: problems that compound other recognized problems having to do with errors in measurement (Diewert and Fox, 1999), trade (Diewert, 2009a, 2010c; Diewert and Woodland, 2004), and how productivity should be measured even with ideal data (Diewert, 1978b, 1981, 2010d; Diewert and Fox, 2010b; Diewert and Morrison, 1986; Diewert and Nakamura, 2003, 2007; Diewert et al., 2010b). For example, Diewert et al. (2010a) explain that so-called transfer prices for goods and services bought and sold between affiliated firms or between administrative units within a firm may often be strategically determined so as to minimize firm tax liabilities. They argue moreover that strategically chosen transfer prices will not usually be suitable for use in an import or export price index. Diewert et al. (2010a) note that already in calendar 2000, the U.S. Bureau of Economic Analysis (BEA) reported that 31 percent of exports and 37 percent of imports were between related parties: that is, between affiliates or different administrative units of the same firm.

Robert E. Lipsey, in his paper, considers a related economic statistics issue arising from the presumed tax minimization strategies of multinational firms (Lipsey, 2010). He argues that, for a multinational firm, owned intangible assets have no clear geographical locations; rather, these assets have nominal locations determined by parent company tax considerations. Lipsey roughly estimates the output and sales of U.S. affiliates in certain tax havens. He argues that the differences between the estimated and reported outputs and sales figures are a rough indication of the extent of the distortions in the income and trade accounts due to tax minimization practices.

Lipsey summarizes evidence of systematic distortions of the values of production and trade. He argues that the inputs for which location is most reliably measured and least likely to be manipulated are labor and physical capital in the form of plant and equipment. He suggests that one sign of distorted measures of output and its location is the reporting of output and profits in locations where 
there is little or no input of labor or capital. Crude measures of the size of the distortions are offered here for a group of mainly small tax havens. Lipsey focuses on these countries because their smallness makes the effects of tax planning most visible. Even for these countries, the estimated distortion is as large as 10 percent of worldwide sales of U.S.-owned affiliates.

In their paper, Jianmin Tang and Henrique do Livramento use data from Statistics Canada's Survey of Innovation (SI) 2005 linked to Annual Survey of Manufacturers (ASM) data to study offshoring with a distinction between material offshoring and R\&D offshoring (Tang and do Livramento, 2010). This paper seeks to address the following questions: What are the factors that are associated with material and R\&D offshoring? Are material and R\&D offshoring associated with a plant's productivity? Is the geographical location of offshoring relevant? The SI covers plants with at least 20 employees and $\$ 250,000$ in revenues from the logging and manufacturing industries. The cross sectional data contain innovation-related information on plant operations and innovation related activities. The information for most of the variables in this study is for 2004 .

\section{INTANGIBLES AND SERVICES}

Diewert has had a long standing interest in the problems raised for price and productivity index measures by new goods, technical change, and obsolescence (Diewert, 1987, 2006b, 2009b, 2009c; Diewert et al., 2003; Diewert and Huang, 2008; Diewert and Schreyer, 2010; Diewert and Wykoff, 2010). Successful research and development (R\&D) investments typically add to the stock of production recipes, and this stock in turn provides a flow of services over time, rather than in one period. Hence, he argues, R\&D resembles more closely capital investment than it does an intermediate input or current consumption. Diewert's position on the nature of R\&D has now been accepted for the System of National Accounts (United Nations et al., 2008). To implement this recommendation, measures for the stock of R\&D capital must be constructed, and this implies a need to determine the depreciation rate of $R \& D$ capital. The knowledge resulting from $R \& D$ constitutes an intangible asset.

Leonard I. Nakamura, in his thought provoking paper, outlines four views on the issue of the general importance of intangibles in private business fixed investment (Nakamura, 2010). In his view, intangibles are assessed as about 48 percent of business fixed investment. He relates the measurement of intangibles to the project of measuring the sources of growth. He also considers three related and difficult areas of the measurement of national income: the measurement of new goods, the deflation of intangible investment, and the divergence between the social and private valuations of intangible assets. He argues that the economic theory and practice underlying measurement of these items is currently controversial and incomplete, and that moving forward requires a shift in the fundamental paradigm of economics, from the "invisible hand" to "creative destruction." $\mathrm{He}$ then presents two simple stylized models, one of which builds on the research of Diewert (1998, 2007, 2009b, 2009c).

Jen Baggs, Eugene Beaulieu, and Loretta Fung observe that the growth of international outsourcing of some service activities has attracted considerable 
media attention in the developed world as white-collar workers in the service sector face increased international competition (Baggs et al., 2010). They note that there is a growing literature addressing the effects of exchange rate movements on manufacturing firms but little concerning firms in the service sector, with this being due in part at least to data gaps. Their paper examines the effects of exchange rate movements on the performance of service firms that are exposed to international trade in five subsectors: communication, finance and insurance, real estate and insurance agent, business services, and part of other services. Overall, their findings suggest significant exchange rate effects on service firms that are qualitatively similar to that found for manufacturing firms. Statistics Canada's T2-LEAP dataset was used for the Baggs-Beaulieu-Fung study. T2-LEAP is a longitudinal dataset that provides information on every incorporated Canadian establishment that legally hires employees and, in the same year, files a "T2" corporate income tax return. T2-LEAP covers the period 1984 through 1998, and for the purposes of this study data from 1986-97 are used: a period of time over which the Canadian dollar experienced both sustained appreciations and depreciations of a similar magnitude.

\section{Special Areas of Methodology Debate}

In his paper, Marshall B. Reinsdorf explains that over the past half century the openness of the world's economies has grown rapidly as lower tariffs and advances in communication and transportation have lowered trading costs and as advances in logistics have made complex, trans-national supply chains more manageable (Reinsdorf, 2010). Export and import prices have therefore taken on an increased importance in determining nations' real consumption possibilities. Foreign trade enables a nation to consume a different mix of goods and services than it produces. Hence, Reinsdorf argues that, to measure real gross domestic income (GDI) for an open economy, it is important to deflate by an index of the prices of the things that this income is used to buy, not the price index for GDP. The differences between these two indexes come from the export and import components of the GDP, and are measured by the trading gains index. Reinsdorf argues that Fisher indexes are a natural way to estimate the conceptual economic indexes of trading gains and real GDI. He argues that Fisher indexes can be decomposed in a way that permits analyses of the factors driving changes in trading gains, such as changes in the terms of trade and in the relative price of tradables, or changes in the prices of particular commodities.

The Reinsdorf paper can be usefully read in conjunction with Diewert's Chapter 24 of the XMPI Manual (Export Import Price Index Manual, IMF et al. 2009). That chapter develops various approaches to measuring the effects on either income generated by the production sector or on a household consumer price index that has directly imported goods and services prices in it (e.g., tourism expenditures abroad). In that chapter, a terms of trade index is defined as an economy's index of export prices divided by an index of import prices. Diewert goes on to help the reader appreciate the complexity of the problem of determining the full effects of changes in real import and export prices on the growth of real income. When export and import prices change, he explains, so do the real prices of consumption, net investment, and government consumption; the volumes of 
labor and capital utilized by the economy's production sector change as well. Also, if export and import prices change, producers will be induced to change the composition of their exports and imports. The work of Diewert and Lawrence (2006) and an appendix of Diewert (2010c) are also useful complements to the Reinsdorf paper. Building on earlier work of his with Morrison (Diewert and Morrison, 1986), Diewert (2010c) decomposes the growth in real income generated by the business sector of the Canadian economy over the years of 1961-2006 into multiplicative year-to-year contributions of six factors. He explains that the product of the second and third factors gives the contribution to real income growth of the combined effects of real changes in the international prices.

Mick Silver, in his paper, first argues that with increasing product differentiation as well as the dwindling availability of customs data, the use of unit value indexes based on customs data is a disservice to price measurement (Silver, 2010). This position is in line with the recommendations for best practice given in IMF et al. (2009), the Export and Import Price Index Manual, where it is suggested that countries using unit value indices move to establishment survey-based price indices and provides a strategy for doing so. This is a departure from international recommendations in United Nations (1981) that are nearly 30 years old. Silver also argues, however, that there are many areas in index number measurement where the use of unit value indices is appropriate. In particular, for homogeneous products and services, it is well recognized that superlative price indices can be misleading and unit value indices are the appropriate target index. Silver then explains that there are many products that are only slightly differentiated. Given that a price index may yield quite different results than a unit value index, there is the obvious question as to whether small differences in quality can justify the loss of the benefits of a unit value index. Quality adjusted prices are an accepted part of index number methodology and such adjustments enable unit value indices to be compiled for items that are not quite homogeneous. This significantly extends the potential use of unit value indices but also raises other questions regarding the use of price index number formulas for aggregating price changes over such products. (For more on the connection to other work of Diewert's, see Diewert et al., 2009a.)

Bert M. Balk, in his paper, points out that productivity change measurement is often carried out under strong assumptions including perfectly competitive input and output markets, optimizing behavior, and constant returns to scale (Balk, 2010). Balk believes (as do we) that for an official statistical agency, whose main task it is to provide statistics to many different users for many different purposes, it is discomforting to have such strong and often empirically refuted assumptions built into the methodological foundations of productivity and growth accounting statistics. Balk proposes to start where the usual story ends, namely at the empirical side. Then, following Balk's vision, after measurement comes explanation, with the assumptions on which the explanation provided depend.

\section{CONCLUSION}

The papers included in this special issue provide a good overview of the current state of research in economic measurement and help illuminate the profound contributions of Diewert to this field. In recent decades problems of measurement 
have perhaps been somewhat neglected by the economics profession. There does now, however, appear to be a resurgence of interest in this field, thanks in large measure to the contributions and leadership of Diewert. Sophisticated modeling requires reliable data. Moreover, it is important that researchers have some appreciation of the origins and underlying strengths and weaknesses of the data they use. We hope this special issue helps to further stimulate interest in this important topic.

\section{REFERENCES}

Baggs, Jen, Eugene Beaulieu, and Loretta Fung, "Are Service Firms Affected by Exchange Rate Movements?" Review of Income and Wealth, 56(Special Issue 1), S156-76, 2010.

Balk, Bert M., "An Assumption-Free Framework for Measuring Productivity Change," Review of Income and Wealth, 56(Special Issue 1), S224-56, 2010.

Caves, D. W., L. R. Christensen, and W. E. Diewert, "Multilateral Comparisons of Output, Input and Productivity using Superlative Index Numbers," Economic Journal, 92(March), 73-86, 1982a.

, "The Economic Theory of Index Numbers and the Measurement of Input, Output, and Productivity," Econometrica, 50, 1392-414, 1982b.

Diewert, W. E., "Exact and Superlative Index Numbers," Journal of Econometrics, 4, 115-45, 1976. , "Superlative Index Numbers and Consistency in Aggregation," Econometrica, 46, 883-900, 1978a.

, "Hicks' Aggregation Theorem and the Existence of a Real Value-Added Function," in M. Fuss and D. McFadden (eds), Production Economics: A Dual Approach to Theory and Applications, Vol. 2, North-Holland, Amsterdam, 17-52, 1978b (reprinted as Chapter 15 in Diewert and Nakamura (1993), pp. 435-70).

, "The Economic Theory of Index Numbers: A Survey," in A. Deaton (ed.), Essays in the Theory and Measurement of Consumer Behaviour in Honour of Sir Richard Stone, Cambridge University Press, London, 163-208, 1981 (reprinted as Chapter 7 in Diewert and Nakamura (1993), pp. 177-221)

, "The Effects of an Innovation: A Trade Theory Approach," Canadian Journal of Economics, 20, 694-714, 1987.

"Exact and Superlative Welfare Change Indicators," Economic Inquiry, 30, 565-82, 1992a.

, "Fisher Ideal Output, Input and Productivity Indexes Revisited," Journal of Productivity Analysis, 3, 211-48, 1992b.

"The CPI Commission: Discussion," American Economic Review, 87, 95-98, 1997.

"Index Number Issues in the Consumer Price Index," Journal of Economic Perspectives, 12, 47-58, 1998.

, "Axiomatic and Economic Approaches to International Comparisons," in A. Heston and R. E. Lipsey (eds), International and Interarea Comparisons of Income, Output and Prices, Studies in Income and Wealth, Vol. 61,University of Chicago Press, 13-87, 1999.

, "The Consumer Price Index and Index Number Purpose," Journal of Economic and Social Measurement, 27, 167-248, 2001.

, "The Quadratic Approximation Lemma and Decompositions of Superlative Indexes," Journal of Economic and Social Measurement, 28, 63-88, 2002a.

, "Harmonized Indexes of Consumer Prices: Their Conceptual Foundations," Swiss Journal of Economics and Statistics, 138, 547-637, 2002b.

- "The Axiomatic and Stochastic Approaches to Index Number Theory," Chapter 16 in Consumer Price Index Manual: Theory and Practice, ILO et al., 289-311, 2004a.

— , "On the Stochastic Approach to Linking the Regions in the ICP," Discussion Paper 04-16, Department of Economics, University of British Columbia, Vancouver, Canada, 2004b.

- "Weighted Country Product Dummy Variable Regressions and Index Number Formulae," Review of Income and Wealth, 51, 561-71, 2005.

_ , "Adjacent Period Dummy Variable Hedonic Regressions and Bilateral Index Number Theory, Annales D’Économie et de Statistique, No. 79/80, 2006 a.

— , "Services and the New Economy: Data Needs and Challenges, Chapter 15 in R. E. Lipsey and A. O. Nakamura (eds), Services Industries and the Knowledge Based Economy, University of Calgary Press, 557-81, 2006b.

, "The Ottawa Group After Ten Meetings: Future Priorities," Discussion Paper 07-01, Department of Economics, University of British Columbia, Vancouver, Canada, 2007.

, "New Methodology for Linking Regional PPPS," ICP (International Comparison Program) Bulletin, 5(2), 1, 10-22 and 45, 2008. 
- "Measuring the Effects of Changes in the Terms of Trade," Chapter 24 in the Export and Import Price Index Manual, Theory and Practice, in IMF et al., 581-602, 2009a.

-, "User Costs versus Waiting Services and Depreciation in a Model of Production," Discussion Paper 09-10, Department of Economics, University of British Columbia, Vancouver, Canada, $2009 \mathrm{~b}$.

— cation," Discussion Paper 09-11, Department of Economics, University of British Columbia, Vancouver, Canada, 2009c.

_ , "New Methodological Developments for the International Comparison Program," Review of Income and Wealth, 56(Special Issue 1), S11-31, 2010a.

- "On the Stochastic Approach to Index Numbers," in W. E. Diewert, B. M. Balk, D. Fixler, K. J. Fox, and A. O. Nakamura (eds), Price and Productivity Measurement, Vol. 6 (Index Number Theory), Trafford Press, 2010b.

- "Changes in the Terms of Trade and Canada's Productivity Performance," in W. E. Diewert, B. M. Balk, D. Fixler, K. J. Fox, and A. O. Nakamura (eds), Price and Productivity Measurement, Vol. 7 (Productivity Performance), Trafford Press, 2010c.

- "Measuring Productivity in the Public Sector: Conceptual Problems," Chapter 4, Vol. 3 in Diewert et al., 2010d.

Diewert, W. E. and K. J. Fox, "Can Measurement Error Explain the Productivity Paradox?" Canadian Journal of Economics, 32, 251-80, 1999.

- "On the Estimation of Returns to Scale, Technical Progress and Monopolistic Markups," Journal of Econometrics, 145, 174-93, 2008.

_ Imperfect Competition," Discussion Paper 10-03, Department of Economics, University of British Columbia, Vancouver, Canada, 2010a.

- "On Measuring the Contribution of Entering and Exiting Firms to Aggregate Productivity Growth," in W. E. Diewert, B. M. Balk, D. Fixler, K. J. Fox, and A. O. Nakamura (eds), Price and Productivity Measurement, Vol. 6 (Index Number Theory), Trafford Press, 2010b.

Diewert, W. E. and R. J. Hill, "Alternative Approaches to Index Number Theory," in W. E. Diewert, B. M. Balk, D. Fixler, K. J. Fox, and A. O. Nakamura (eds), Price and Productivity Measurement, Vol. 6 (Index Number Theory), Trafford Press, 2010.

Diewert, W. E. and N. Huang, "Capitalizing R\&D Expenditures," Discussion Paper 04-08, Department of Economics, University of British Columbia, Vancouver, Canada, 2008.

Diewert, W. E. and D. Lawrence, Measuring the Contributions of Productivity and Terms of Trade to Australia's Economic Welfare, Report by Meyrick and Associates to the Productivity Commission, Canberra, 2006.

Diewert, W. E. and H. Mizobuchi, "Exact and Superlative Price and Quantity Indicators," Macroeconomic Dynamics, 13(Supplement 2), 335-80, 2009.

Diewert, W. E. and C. J. Morrison, "Adjusting Output and Productivity Indexes for Changes in the Terms of Trade," Economic Journal, 96, 659-79, 1986.

Diewert, W. E. and A. O. Nakamura (eds), Essays in Index Number Theory, Vol. 1, Contributions to Economic Analysis 217, North-Holland, Amsterdam, 1993

_ "Index Number Concepts, Measures and Decompositions of Productivity Growth," Journal of Productivity Analysis, 19, 127-59, 2003.

- "The Measurement of Productivity for Nations," in J. J. Heckman and E. E. Leamer (eds), Handbook of Econometrics, Vol. 6A, Elsevier Science, 4502-86, 2007.

Diewert, W. E. and P. Schreyer, "Capitalized Net Product as a Discrete Time Proxy for Discounted Optimal Consumption,” in W. E. Diewert, B. M. Balk, D. Fixler, K. J. Fox, and A. O. Nakamura (eds), Price and Productivity Measurement, Vol. 8 (Capital and Income), Trafford Press, 2010.

Diewert, W. E. and A. D. Woodland, "The Gains from Trade and Policy Reform Revisited," Review of International Economics, 12, 591-608, 2004.

Diewert, W. E. and F. C. Wykoff, "Depreciation, Deterioration and Obsolescence when There Is Embodied or Disembodied Technical Change," in W. E. Diewert, B. M. Balk, D. Fixler, K. J. Fox, and A. O. Nakamura (eds), Price and Productivity Measurement, Vol. 8, Trafford Press, 2010.

Diewert, W. E., A .O. Nakamura, and P. Tiessen, "Information Failure as an Alternative Explanation of Under Investment in R\&D," Journal of Managerial Decision Economics, 24, 231-9, 2003.

Diewert, W. E., S. Heravi, and M. Silver, "Hedonic Imputation versus Time Dummy Indexes," in W. E. Diewert, J. Greenlees, and C. R. Hulten (eds), Price Index Concepts and Measurement, NBER, Studies in Income and Wealth, Vol. 70, University of Chicago Press, 161-202, 2009a.

Diewert, W. E., M. Huwiler, and U. Kohli, "Retrospective Price Indices and Substitution Bias," Swiss Journal of Economics and Statistics, 145, 127-35, 2009b. 
Diewert, W. E., W. F. Alterman, and L. Eden, "Transfer Prices and Import and Export Price Indexes: Theory and Practice," in W. E. Diewert, B. M. Balk, D. Fixler, K. J. Fox, and A. O. Nakamura (eds), Price and Productivity Measurement, Vol. 4 (International Comparisons and Trade), Trafford Press, 2010a.

Diewert, W. E., T. Nakajima, A. O. Nakamura, E. Nakamura, and M. Nakamura, "Returns to Scale: Concept and Estimation," in W. E. Diewert, B. M. Balk, D. Fixler, K. J. Fox, and A. O. Nakamura (eds), Price and Productivity Measurement, Vol. 7 (Productivity Performance), Trafford Press, 2010b.

Feenstra, R. C., "Exact Hedonic Price Indexes," Review of Economics and Statistics, 77, 634-53, 1995.

Hajargasht, Gholamreza and D. S. Prasada Rao, "Stochastic Approach to Index Numbers for Multilateral Price Comparisons and their Standard Errors," Review of Income and Wealth, 56(Special Issue 1), S32-58, 2010.

Hill, R. J., "Comparing Price Levels across Countries Using Minimum Spanning Trees," Review of Economics and Statistics, 81, 135-42, 1999a.

—_, "International Comparisons using Spanning Trees," in A. Heston and R. E. Lipsey (eds), International and Interarea Comparisons of Income, Output and Prices, Studies in Income and Wealth, Vol. 61, NBER, University of Chicago Press, 109-20, 1999b.

- "Constructing Price Indexes across Space and Time: The Case of the European Union," American Economic Review, 94, 1379-410, 2004.

ILO, IMF, OECD, UNECE, Eurostat, and World Bank, Consumer Price Index Manual: Theory and Practice (CPI Manual), Geneva, http://www.ilo.org/public/english/bureau/stat/guides/cpi/ index.htm, 2004

IMF, ILO, OECD, UNECE, Eurostat, and World Bank, Producer Price Index Manual: Theory and Practice (PPI Manual), http://www.imf.org/external/np/sta/tegppi/index.htm, 2004.

- Export and Import Price Index Manual: Theory and Practice (XMPI Manual), http:// www.imf.org/external/np/sta/tegeipi/, 2009.

Kohli, U. "A Symmetric Normalized Quadratic GNP Function and the U.S. Demand for Imports and Supply of Exports," International Economic Review, 34, 243-55, 1993.

Lipsey, Robert E., "Measuring the Location of Production in a World of Intangible Productive Assets, FDI, and Intrafirm Trade," Review of Income and Wealth, 56(Special Issue 1), S99-110, 2010.

Nakamura, Leonard I., "Intangible Assets and National Income Accounting," Review of Income and Wealth, 56(Special Issue 1), S135-55, 2010.

Nakamura, E. and J. Steinsson, "Five Facts About Prices: A Reevaluation of Menu Cost Models," Quarterly Journal of Economics, 123, 1415-64, 2008.

Rao, D. S. Prasada, Alicia Rambaldi, and Howard Doran, "Extrapolation of Purchasing Power Parities Using Multiple Benchmarks and Auxiliary Information: A New Approach," Review of Income and Wealth, 56(Special Issue 1), S59-98, 2010.

Reinsdorf, Marshall B., "Terms of Trade Effects: Theory and Measurement," Review of Income and Wealth, 56(Special Issue 1), S177-205, 2010.

Silver, Mick, "The Wrongs and Rights of Unit Value Indices," Review of Income and Wealth, 56(Special Issue 1), S206-23, 2010.

Summers, R., "International Comparisons with Incomplete Data," Review of Income and Wealth, 29, $1-16,1973$

Tang, Jianmin and Henrique do Livramento, "Offshoring and Productivity: A Micro-Data Analysis," Review of Income and Wealth, 56(Special Issue 1), S111-34, 2010.

United Nations, Department of International Economic and Social Affairs, "Strategies for Price and Quantity Measurement in External Trade," Statistical Papers, Series M, No. 69, 1981.

United Nations, Commission of the European Communities, IMF, OECD, and World Bank, System of National Accounts 2008, 2008.

Van Ark, B., A. Maddison, and M. P. Timmer, "Purchasing Power Parity Measurement for Industry of Origin Analysis," ICP Bulletin, 5(1), 29-34, http://siteresources.worldbank.org/ICPINT/ Resources/270056-1208272795236/ICP_bulletin_03-04_web.pdf, 2008. 